\title{
BMJ Global Health Achieving universal health coverage in small island states: could importing health services provide a solution?
}

\author{
Mariyam Suzana, ${ }^{1}$ Helen Walls, ${ }^{2}$ Richard Smith, ${ }^{2}$ Johanna Hanefeld ${ }^{2}$
}

To cite: Suzana M, Walls $\mathrm{H}$, Smith R, et al. Achieving universal health coverage in small island states: could importing health services provide a solution?BMJ Glob Health 2018;3:e000612. doi:10.1136/ bmjgh-2017-000612

Handling editor Seye Abimbola

Received 18 October 2017 Revised 16 November 2017 Accepted 17 November 2017
Check for updates

${ }^{1}$ Faculty of Health Sciences, The Maldives National University, Male, Maldives

${ }^{2}$ Department of Global Health and Development, London School of Hygiene \& Tropical Medicine, London, UK

Correspondence to Dr Johanna Hanefeld; johanna.hanefeld@Ishtm.ac.uk

\section{ABSTRACT}

Background Universal health coverage (UHC) is difficult to achieve in settings short of medicines, health workers and health facilities. These characteristics define the majority of the small island developing states (SIDS), where population size negates the benefits of economies of scale. One option to alleviate this constraint is to import health services, rather than focus on domestic production. This paper provides empirical analysis of the potential impact of this option.

Methods Analysis was based on publicly accessible data for 14 SIDS, covering health-related travel and health indicators for the period 2003-2013, together with indepth review of medical travel schemes for the two highest importing SIDS-the Maldives and Tuvalu.

Findings Medical travel from SIDS is accelerating. The SIDS studied generally lacked health infrastructure and technologies, and the majority of them had lower than the recommended number of physicians in a country, which limits their capacity for achieving UHC. Tuvalu and the Maldives were the highest importers of healthcare and notably have public schemes that facilitate medical travel and help lower the out-of-pocket expenditure on medical travel. Although different in approach, design and performance, the medical travel schemes in Tuvalu and the Maldives are both examples of measures used to increase access to health services that cannot feasibly be provided in SIDS.

Interpretation Our findings suggest that importing health services (through schemes to facilitate medical travel) is a potential mechanism to help achieve universal healthcare for SIDS but requires due diligence over cost, equity and quality control.

\section{INTRODUCTION}

Universal health coverage (UHC) refers to a healthcare system that provides coverage of quality healthcare and financial protection to all citizens of a country. ${ }^{1}$ It has become the globally accepted concept for advocating access to, and affordability of, healthcare and is recognised in the Sustainable Development Goals. ${ }^{2}$ For countries to achieve UHC, a set of prerequisites are needed, such as political will and stakeholder support for predominantly public sector funding. ${ }^{3}$ The WHO also proposes four essential attributes

\section{Key questions}

What is already known about this topic?

- Much analysis of the medical travel market has identified that medical travel is growing, although at a slower pace than originally projected.

- A systematic review of medical travel literature observed that the effects on the originating (importing) countries' health system were mainly perceived as negative. These include patients returning with complications, rising costs and lack of regulation in the industry.

- However, findings across the different studies suggested that the impact on a country's health system depends on the context and capacity.

\section{What are the new findings?}

- The multicountry analysis presented here is the first of medical travel among small island developing states (SIDS), and the findings confirm that the import of health services among SIDS has occurred at a slower pace than the projected rise of the global medical travel industry.

- The non-linear growth of medical travel among SIDS gives evidence that the industry is volatile to external shocks, which is a factor that needs to be taken into consideration by SIDS considering import as a mechanism to increase access to health services.

- While existing literature notes the scarcity of institutionalised arrangements for medical travel, our findings highlight the success of three government-funded schemes among SIDS. The Tuvalu Medical Treatment Scheme spent 44.5\% of its health budget on overseas treatment in 2013, while the Maldivian government spent $\$ 11.6$ million on subsidised medical travel in 2012 and highly specialised treatment worth $\$ 1.53$ million per annum was funded by the Seychelles government.

for achieving UHC: an efficient and well-run health system; an affordable and equitable system for financing; access to essential medicines and technologies; and a sufficiently trained and motivated health workforce. ${ }^{3}$

Shortages of medicines, health workers and health facilities are major impediments to 


\section{Key questions}

\section{Recommendations for policy}

- In settings with small health systems and extreme resource constraints, state- led strategic importing of health services using regional integration could be a potential mechanism to help achieve universal health coverage in SIDS. However, appropriate due diligence over cost, equity and quality control needs to be taken to minimise the perceived negative consequences from this trade.

moving towards UHC and are characteristics that typify most small island developing states (SIDS). Thirty-nine countries are defined as SIDS, characterised by their narrow economic base, high production costs, shortage of skilled labour and heavy dependence on trade and foreign aid. ${ }^{45}$ The majority of SIDS receive high levels of overseas development assistance, and bilateral and multilateral trade has been one strategy that SIDS have used to overcome domestic shortages. ${ }^{6}$ While there are benefits to trade, there is a clear need for caution when liberalising trade, including healthcare. Walls et $a l^{7}$ highlight that trade negotiations themselves, and the ongoing management of trade agreements once signed, can become a burden on the governments of smaller and poorer states. Yet, there is a dearth of systematic cataloguing and analysis of trade policy initiatives and their impact on health systems, leaving an incomplete picture of their nature and effects. ${ }^{8}$ This is especially true when it comes to SIDS, and this is the gap that this paper seeks to fill through the comparative analysis of the experience of a large group of SIDS.

Cross-country comparison of health system performance, if undertaken appropriately, can provide a powerful method for identifying strengths and weaknesses of reforms relevant to similar settings. ${ }^{9}$ This paper presents a cross-country comparison focused on medical travel to understand the pattern of consumption of health services abroad by SIDS, mapping the linkages between the import of health services and the health indicators relevant to achieving UHC. On this basis, we analyse how import of services through public medical travel schemes affects access to quality health services and UHC for SIDS.

\section{METHODS}

\section{Study design}

Quantitative analysis was conducted on sets of longitudinal secondary data on health-related travel and health indicators covering the period 2003-2013. A review of policy documents was used to understand, where possible, the reasons for the observed trends and patterns identified by the quantitative analysis. The study covered all SIDS that are member states of the UN and that reported health-related travel data to the International Monetary Fund (IMF), which are presented in table 1.
We developed a framework for analysis based on the WHO building blocks framework (2007), ${ }^{10}$ reflecting the four core dimensions of UHC (table 2). Two health indicators per dimension were selected, based primarily on data availability. To understand the relationship between each dimension of UHC and the import of health services, each pair of indicators was then mapped onto the outcome variable 'health-related travel expenditure (HRT)', for the period 2003-2013.

\section{Sources of data}

Data for the study were obtained from three sources: the IMF, the World Bank (WB) and the WHO. Data addressing the main outcome variable, 'Health-related travel expenditure \$' were obtained from the IMF databank online. From the annually published balance of payments (BOP) data by the IMF, the item 'Health-related travel expenditures (personal) in current USD' was acquired for the years 2003-2013 for all the SIDS that reported these data. In the BOP, the item is presented under 'Current Account/Goods and Services/Services/Travel/Personal/Health related, Debit, US Dollars' for expenditures. According to the BOP manual, the travel component covers the goods and services acquired from an economy by travellers during visits of less than 1 year in that economy. ${ }^{11}$ Four broad approaches are used by Member States to measure travel expenditure, and the table in online supplementary annex 1 summarises the sources and methodologies used by the selected SIDS to report health-related travel data to the IMF. The WB data bank provided country-level indicators for the years 20032013 on health expenditure public (as a proportion of total health expenditure (THE) ) (2003-2013), and out-of-pocket expenditure (OOP) health expenditure (as a proportion of THE) (2003-2013), while statistics from WHO (2015) were used to obtain indicators on health infrastructures and health technologies, health personnel and service coverage indicators. The two highest importers having the steepest rises in per capita HRT during the study period were selected, and policy documents relating to these two countries by three international donor agencies $(\mathrm{WHO}, \mathrm{WB}$ and IMF) were reviewed (table 3 summarises the documents reviewed for each country).

\section{Data management and analysis}

The unit of analysis is the country. HRT per capita was derived by dividing HRT by the total population for each year. Median, IQR and percentages were used to describe data. Bubble charts that can show the relation between three different sets of variables were used to map the linkages between health indicators and health-related travel. Where indicator data were available for a certain year(s), the HRT data in the bubble represent the same year(s) as the indicators on the $\mathrm{x}$ and $\mathrm{y}$ axes. In this analysis, the $\mathrm{x}$ and $y$ axes present the related indicators, and the data points represent the location of the country with regard to the indicators on the axes. The size of the bubble represents the amount spent on medical travel against the backdrop of each system needed for UHC. For instance, countries 
Table 1 Characteristics of small island developing states (SIDS)

\begin{tabular}{|c|c|c|c|c|c|c|}
\hline \multirow{2}{*}{$\begin{array}{l}\text { SIDS by WHO } \\
\text { region }\end{array}$} & $\begin{array}{l}\text { Land area } \\
\text { (sq. } \mathrm{km})\end{array}$ & $\begin{array}{l}\text { Total } \\
\text { population }\end{array}$ & $\begin{array}{l}\text { Health } \\
\text { expenditure } \\
\text { per capita \$ }\end{array}$ & $\begin{array}{l}\text { Net ODA } \\
\text { per capita } \\
\text { (current \$) }\end{array}$ & $\begin{array}{l}\text { Trade in } \\
\text { services as } \\
\% \text { of GDP }\end{array}$ & Top 5 import partners 2014 \\
\hline & 2013 & 2013 & 2013 & 2013 & 2013 & $\mathrm{n}=$ total number of import partners \\
\hline \multicolumn{7}{|l|}{$\begin{array}{l}\text { Regional officie for } \\
\text { the Western Pacific } \\
\text { (WPRO) }\end{array}$} \\
\hline Fiji & 18270 & 880487 & 189 & 103 & 46.38 & $\begin{array}{l}\mathrm{n}=168 \text {, Singapore, Australia, New } \\
\text { Zealand, China, France }\end{array}$ \\
\hline Marshall Islands & 180 & 52786 & 630 & 1776 & & $\begin{array}{l}\text { South Korea, China, Germany, Turkey } \\
\text { and Poland }\end{array}$ \\
\hline Tonga & 720 & 105139 & 204 & 764 & $34.55(2012)$ & $\begin{array}{l}\mathrm{n}=86, \text { New Zealand, Singapore, USA, } \\
\text { Japan, Fiji }\end{array}$ \\
\hline Tuvalu & 30 & 9876 & 704 & 2703 & $110.27(2008)$ & $\begin{array}{l}\mathrm{n}=28, \text { Fiji, Australia, New Zealand, } \\
\text { Japan, other Asian countries }\end{array}$ \\
\hline Vanuatu & 12190 & 253165 & 123 & 358 & $54.40(2011)$ & $\begin{array}{l}\mathrm{n}=99, \text { Australia, Singapore, New } \\
\text { Zealand, Fiji, China }\end{array}$ \\
\hline \multicolumn{7}{|l|}{$\begin{array}{l}\text { Pan } \\
\text { AmericanHealth } \\
\text { Organisation }\end{array}$} \\
\hline Bahamas & 10010 & 377841 & 1621 & & 49.53 & $\begin{array}{l}\mathrm{n}=100 \text {, USA, Barbados, Trinidad } \\
\text { \&Tobago, Japan }\end{array}$ \\
\hline Belize & 22810 & 344193 & 262 & 144 & 40.38 & $\begin{array}{l}\mathrm{n}=120 \text {, USA, Curacao, Mexico, China } \\
\text { Guatemala }\end{array}$ \\
\hline Barbados & 430 & 282503 & 1007 & & $53.36(2010)$ & $\begin{array}{l}\mathrm{n}=177, \text { USA, Trinidad \& Tobago, } \\
\text { China, UK, Suriname }\end{array}$ \\
\hline \multicolumn{7}{|l|}{ AFRO } \\
\hline Cape Verde & 4030 & 507258 & 165 & 480 & 56.02 & $\begin{array}{l}\mathrm{n}=101 \text {, Portugal, The Netherlands, } \\
\text { Spain, Brazil, China }\end{array}$ \\
\hline Comoros & 1861 & 751697 & 51 & 109 & 27.26 (2009) & $\begin{array}{l}\mathrm{n}=79, \mathrm{UAE} \text {, France, Pakistan, China, } \\
\text { South Africa }\end{array}$ \\
\hline Guinea-Bissau & 28120 & 1757138 & 32 & 59 & 7.9 (2005) & $\begin{array}{l}\mathrm{n}=24 \text {, Senegal, Portugal, Thailand, } \\
\text { The Netherlands, France }\end{array}$ \\
\hline $\begin{array}{l}\text { Sao Tome and } \\
\text { Principe }\end{array}$ & 960 & 182386 & 110 & 284 & 39.21 & $\begin{array}{l}\mathrm{n}=63 \text {, Portugal, Angola, China, USA, } \\
\text { Gabon }\end{array}$ \\
\hline Seychelles & 455 & 89900 & 551 & 283 & 73.17 (2008) & $\begin{array}{l}\mathrm{n}=160 \text {, UAE, Saudi Arabia, Singapore, } \\
\text { Germany, France }\end{array}$ \\
\hline \multicolumn{7}{|l|}{$\begin{array}{l}\text { South East Asia } \\
\text { Region }\end{array}$} \\
\hline Maldives & 300 & 393000 & 720 & 58 & 116.69 & $\begin{array}{l}\mathrm{n}=87, \text { UAE, Singapore, India, } \\
\text { Malaysia, Sri Lanka }\end{array}$ \\
\hline
\end{tabular}

Source: The World Bank..$^{30} 31$

AFRO, r egional office for Africa; GDP, gross domestic product; ODA, overseas development assistance; PAHO, Pan American Health Organisation; SEAR, South East Asia Region; WPRO, regional office for Western Pacific.

scoring high on skilled birth Attendents (SBA) and antenatal care (ANC) indicators show a strong, efficient and well-run domestic health system, while the size of the bubble would be an implication of the deficiencies in that system.

Role of the funding source

The funding source did not have any involvement in the design, collection, analysis and interpretation of the data presented in the paper or in the decision to submit the paper for publication. However, the salary of the corresponding author was covered by the funding source. The corresponding author confirms that she had full access to all the data in the study and had final responsibility for the decision to submit for publication.

\section{RESULTS}

Fourteen of the 39 SIDS reported health-related travel data to the IMF. As shown in figure 1, a rising trend was observed in health-related travel expenses over the 
Table 2 Indicators addressing key health system attributes for universal healthcare

\begin{tabular}{|c|c|c|}
\hline Systems required for UHC & Indicators & Source \\
\hline $\begin{array}{l}\text { A strong, efficient, well-run health } \\
\text { system }\end{array}$ & $\begin{array}{l}\text { Births attended by skilled health personnel (\%) } \\
\text { (2007-2014) } \\
\text { Antenatal care coverage at least four visits (\%) } \\
(2007-2014)\end{array}$ & $\begin{array}{l}\text { World health statistics, WHO } \\
2015^{32}\end{array}$ \\
\hline $\begin{array}{l}\text { A system for financing health } \\
\text { services }\end{array}$ & $\begin{array}{l}\text { Health expenditure public (as a \% of THE) (2003- } \\
2013 \text { ) } \\
\text { OOP health expenditure (as a \% of THE) (2003-2013) }\end{array}$ & World Bank databank, $2016^{30}$ \\
\hline $\begin{array}{l}\text { A sufficient capacity of well-trained, } \\
\text { motivated health workers }\end{array}$ & $\begin{array}{l}\text { Number of physicians per } 10000 \text { population (2007- } \\
2013 \text { ) } \\
\text { Number of nursing and midwifery personnel per } \\
10000 \text { population (2007-2013) }\end{array}$ & World health statistics, WHO 2015 \\
\hline
\end{tabular}

OOP, out-of-pocket expenditure; THE, total health expenditure; UHC, universal health coverage.

10 -year period across the 14 countries. Median expenditures across the countries rose 4.5 times between 2003 and 2013 , from $\$ 0.68$ to $\$ 3.11$ million, while a few SIDS were found to have extremely high per capita expenditure (figure 2).

Although expenditure on health-related travel by the SIDS increased over time, it was not linear for any country. Notable fluctuations in medical travel were observed for many countries, particularly from 2009 to 2012, which may reflect issues of data quality or reporting. By 2013, Tuvalu, the Maldives and the Seychelles were observed to be the top importers of health services among the SIDS. While it is beyond the scope of this paper to explore the individual travel growth patterns of SIDS, we examined the relationship between health-related travel and health systems of these countries.

Table 4 indicates that all SIDS perform well on the service coverage indicators that were used to represent a well-running health system, except for Guinea Bissau, which had very low access to skilled birth attendance. In health financing, WPRO SIDS generally perform better than other regions with high public expenditure and very low OOP. Tuvalu had almost $100 \%$ of its health expenditures borne by the government. Health infrastructures and technologies range on average 1-10 hospitals per 100000 populations and $0-13$ CTs per one million populations respectively. Access to health workforce were lowest in Guinea Bissau (0.7 and 5.9) and Cape Verde (3.1 and 5.6), while it was highest in Bahamas (28.2 and 41.4).

Figures 3-6 show HRTs among SIDS mapped across the health systems indicators identified for UHC dimensions in our framework.

Mapped across the health service coverage indicators, all SIDS were seen to perform well on coverage. The Maldives and Tuvalu, represented by the largest two bubbles, are observed to perform better on service indicators than the lowest importers of health services (Comoros and Vanuatu). Outliers Guinea Bissau and Vanuatu, which had lower levels of service coverage compared with other SIDS, also experienced low levels of import of health services.

A more linear pattern was observed between the public health expenditure and OOP health expenditure. Two large bubbles (the Maldives and Bahamas) were found at high levels of OOP spending. The largest bubble representing Tuvalu had very high levels of public health spending and very low OOP spending. Among the lowest importers of health services, Vanuatu had a very low OOP and high public expenditure on health, while Comoros's health financing indicators were very low on both indicators.

Table 3 Sources of data for qualitative analysis

\begin{tabular}{llll}
\hline Region & Selected country & Policy documents analysed & Country reviews by WHO and WB \\
\hline WPRO & Tuvalu & $\begin{array}{l}\text { Tuvalu Strategic Health plan 2009-2018, }{ }^{27} \\
\text { Medical treatment scheme guideline, NHA }\end{array}$ & $\begin{array}{l}\text { WHO: country cooperation strategy } \\
\text { brief (May 2014), }{ }^{33} \text { Statement of the IMF } \\
\text { Mission }{ }^{28}\end{array}$ \\
SEAR & Maldives & NHA 2011, ${ }^{34}$ Health master plan 2016-2025 WB: Maldives Health Policy Note (March & 2013) \\
& & WHO: country cooperation strategy brief \\
& & $2013-2017^{36}$
\end{tabular}

IMF, International Monetary Fund; WB, World Bank. 


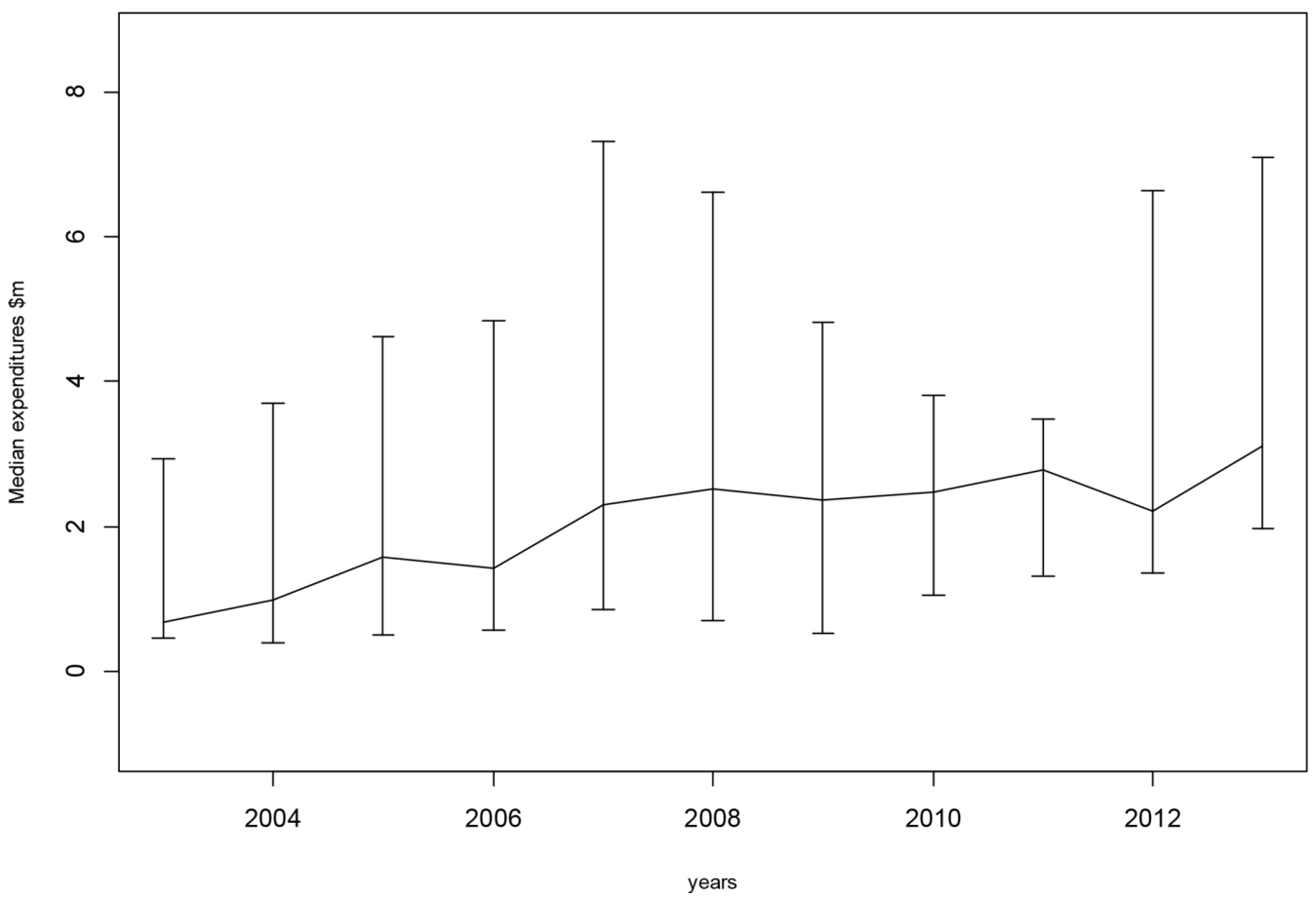

Figure 1 Trend of expenditure on health-related travel among 14 SIDS, 2003-2013. SIDS, small island developing states.

Health-related travel mapped across the health workforce indicators showed that the largest bubbles were located at higher levels of nursing and midwifery personnel and around 10-15 physicians per 1000 population. The Bahamas and the Marshall Islands had very contrasting levels of health workforce but experienced

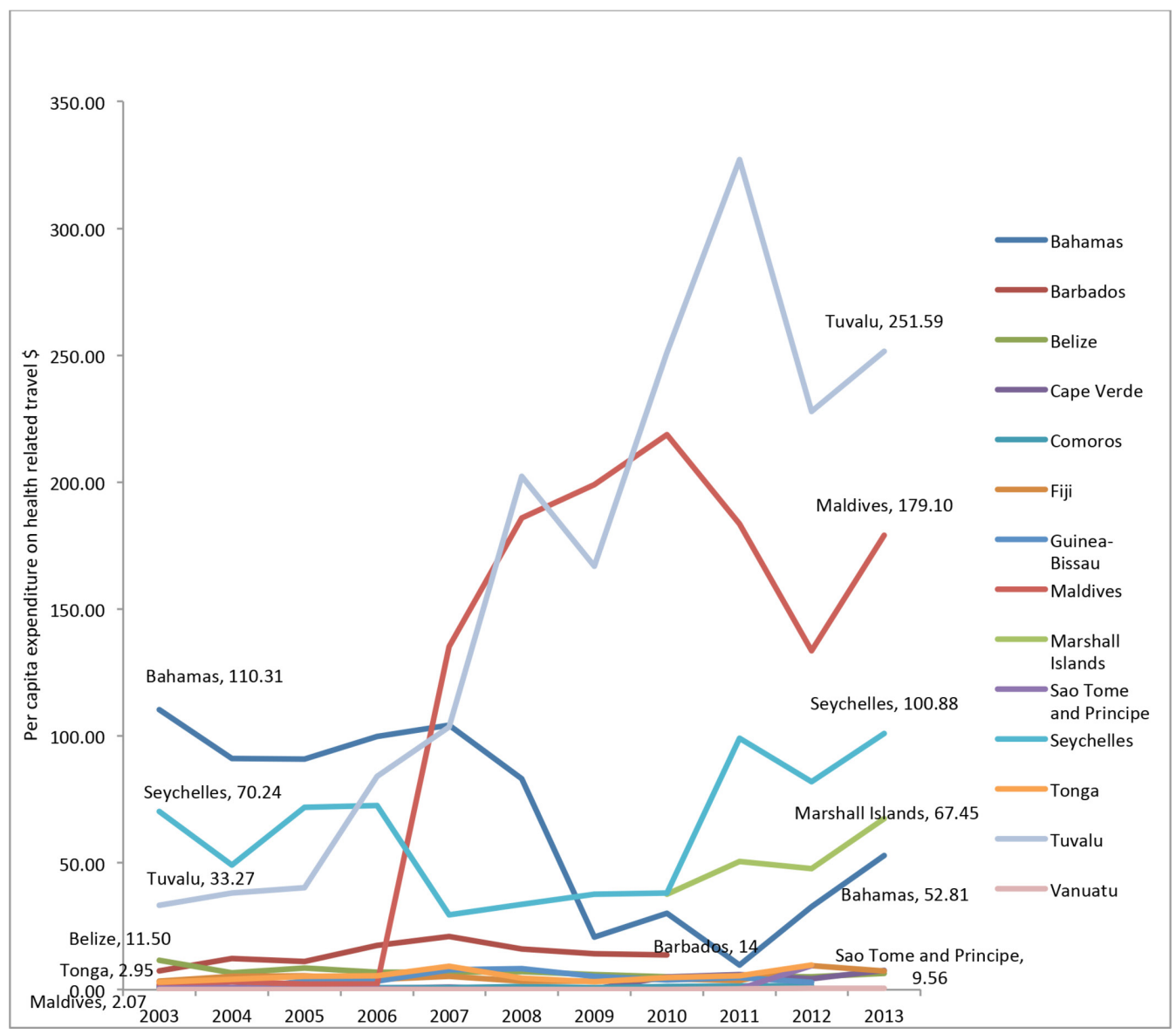

Figure 2 Per capita health-related travel expenditures among 14 small island developing states, 2003-2013. 


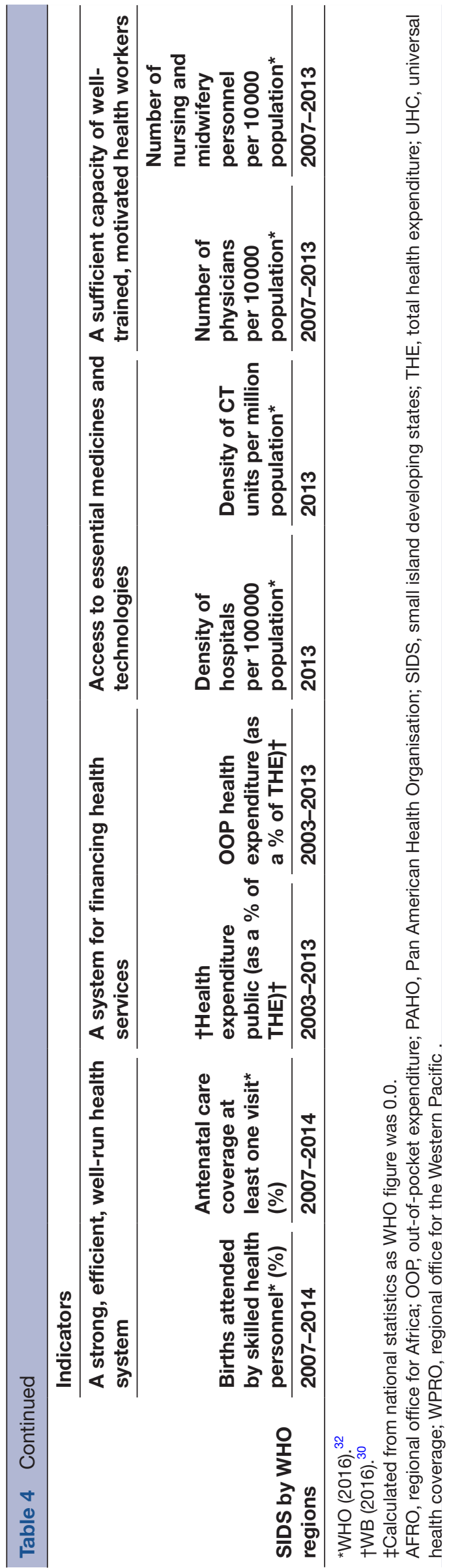

similar levels of HRT. The majority of the bubbles were located where health workforce was lower than 13.9 physicians and 28.6 nursing personnel per 10000 population, which are the global averages for the two indicators. Thus, these countries have lower than the recommended WB ratio of 23 doctors, nurses and midwives per 100000 .

Based on the two indicators used to represent health infrastructures and medical technology, all SIDS faced shortages in health infrastructure and technologies that may reflect the small populations these countries serve. Both large and small bubbles were located where hospitals per 100000 population were less than 10 and access to technologies were less than 20 units per 1 million population. These were however above the global medians of 1.1 hospital per 100000 population and 3.8 units per 1 million population.

Table 5 provides a description of medical travel schemes in the two SIDS, Tuvalu and the Maldives, which the quantitative analysis demonstrated had the highest and most fluctuating trends during the study period. It shows that through medical travel, both the Maldives and Tuvalu appear to have increased access to health services unavailable within each country previously, which may have been spent from out-of-pocket. With the government directly approaching foreign health providers, the Maldives compared with Tuvalu is found to be providing a more comprehensive set of services to a greater number of patients at a smaller per capita health budget. However, the multilateral approach by Tuvalu has the ability to reduce the burden of OOP as it covers the full cost of travel episode and offers services of foreign specialists through the scheme.

\section{DISCUSSION}

Based on analysis of 14 SIDS, there appears to be a gradual but fluctuating trend of medical travel. Analysis of medical travel vis-à-vis core health system dimensions required to achieve UHC identified major shortages in the areas of health infrastructure and technology. At the same time, coverage of (more limited) services that the countries are able to provide is exceptionally high. While Tuvalu and the Maldives were found to be the top importers of healthcare, and experienced the most significant growth in medical travel, this appears to be due to the public funding available to facilitate this. Although their approach, design and performance were slightly different, the two public schemes in Tuvalu and the Maldives suggest how an increase in access to health services may be achieved through medical travel. This study suggests that strategic importing of health services could be a promising mechanism to help SIDS achieve UHC.

Much analysis in medical travel literature has identified that it is growing, although at a slower pace than originally projected, with specific regional and heterogeneous patterns, and that it is a diverse industry. ${ }^{812-14}$ The analysis presented here is the first of medical travel among SIDS, and findings confirm this heterogeneous pattern. ${ }^{15}$ Analysis 


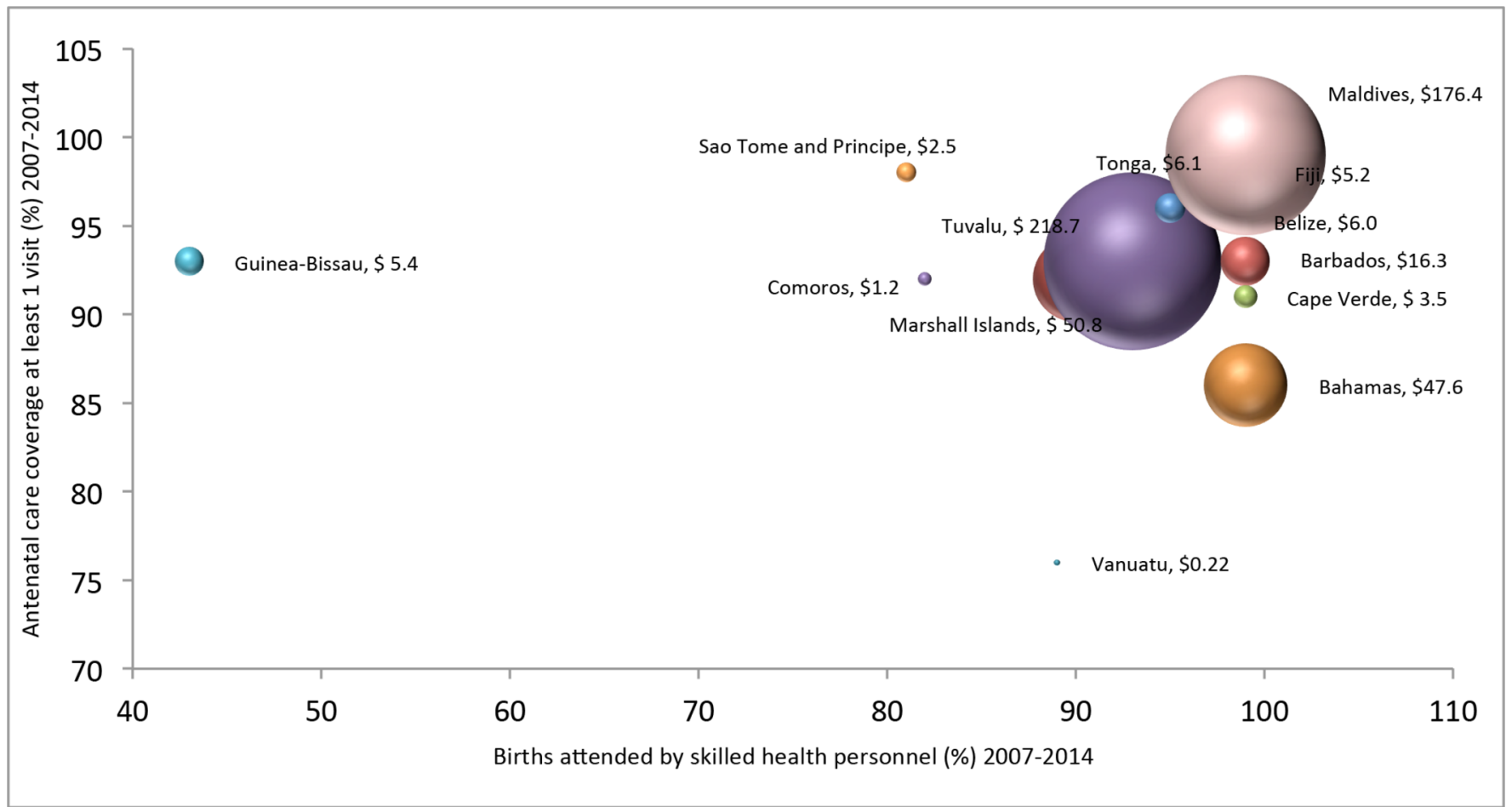

Figure 3 Health-related travel against health service coverage indicators, 2007- 2014.

of data from 140 economies in the travel and tourism competitiveness report of 2011 indicates that the industry has witnessed contractions since 2009 due to the global economic crisis, volatile oil prices, climatic disturbances, multiple security incidents and pandemics ${ }^{16}$ may explain the non-linear growth of medical travel across SIDS.
The SIDS analysed here generally lacked health infrastructure and technologies that will affect their capacity to achieve UHC. However, this is not inherent in all SIDS. Countries such as Belize (\$0.1 million), Barbados (\$2.4 million), Cape Verde (\$0.01 million), Tonga (\$0.006 million) and Tuvalu (\$0.004 million) have

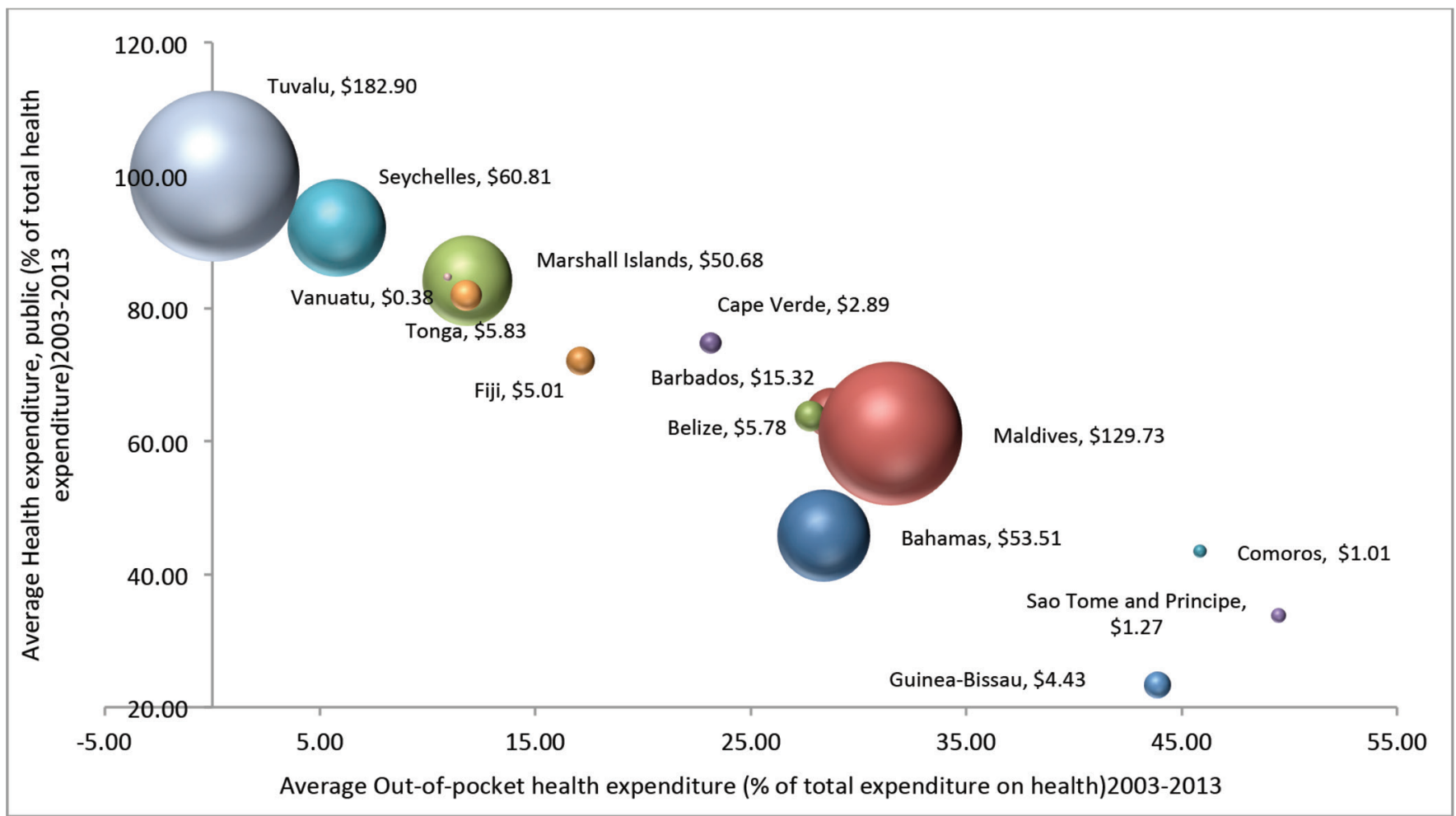

Figure 4 Average expenditure on health-related travel per capita versus health financing structure, 2003-2013. 


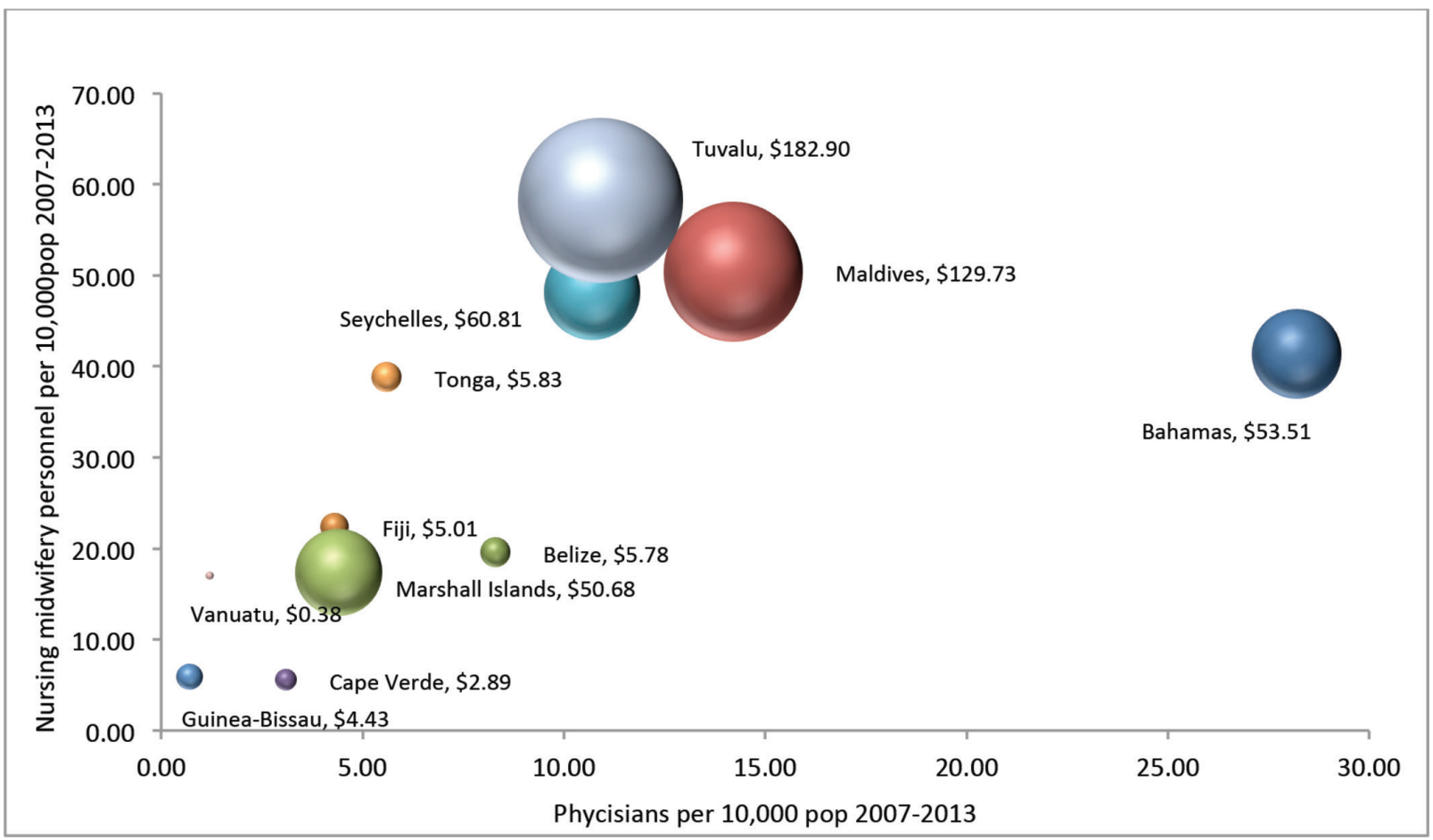

Figure 5 Average health-related travel per capita versus health workforce, 2005-2013.

innovatively earned an income from health-related travel as well. According to the BOP manual, income covers two types of transactions between residents and non-residents; compensation of employees paid to non-resident workers and investment income receipts and payments on external financial assets and liabilities. Reports of income generated directly by medical tourism in SIDS is very rare except for few cases such as by the island state of Penang in Malaysia, which contributes more than $50 \%$ of the country's medical tourism market with seven of its hospitals actively involved in medical tourism. ${ }^{17}$ The growth of medical tourism in Barbados serving the Carribean, Mexican and the British patients have also been highlighted, although monetary benefits have not been mentioned. ${ }^{18}$ These bidirectional flows of trade in health services deserve greater investigation to understand better the factors that allow SIDS to act as exporters of services.

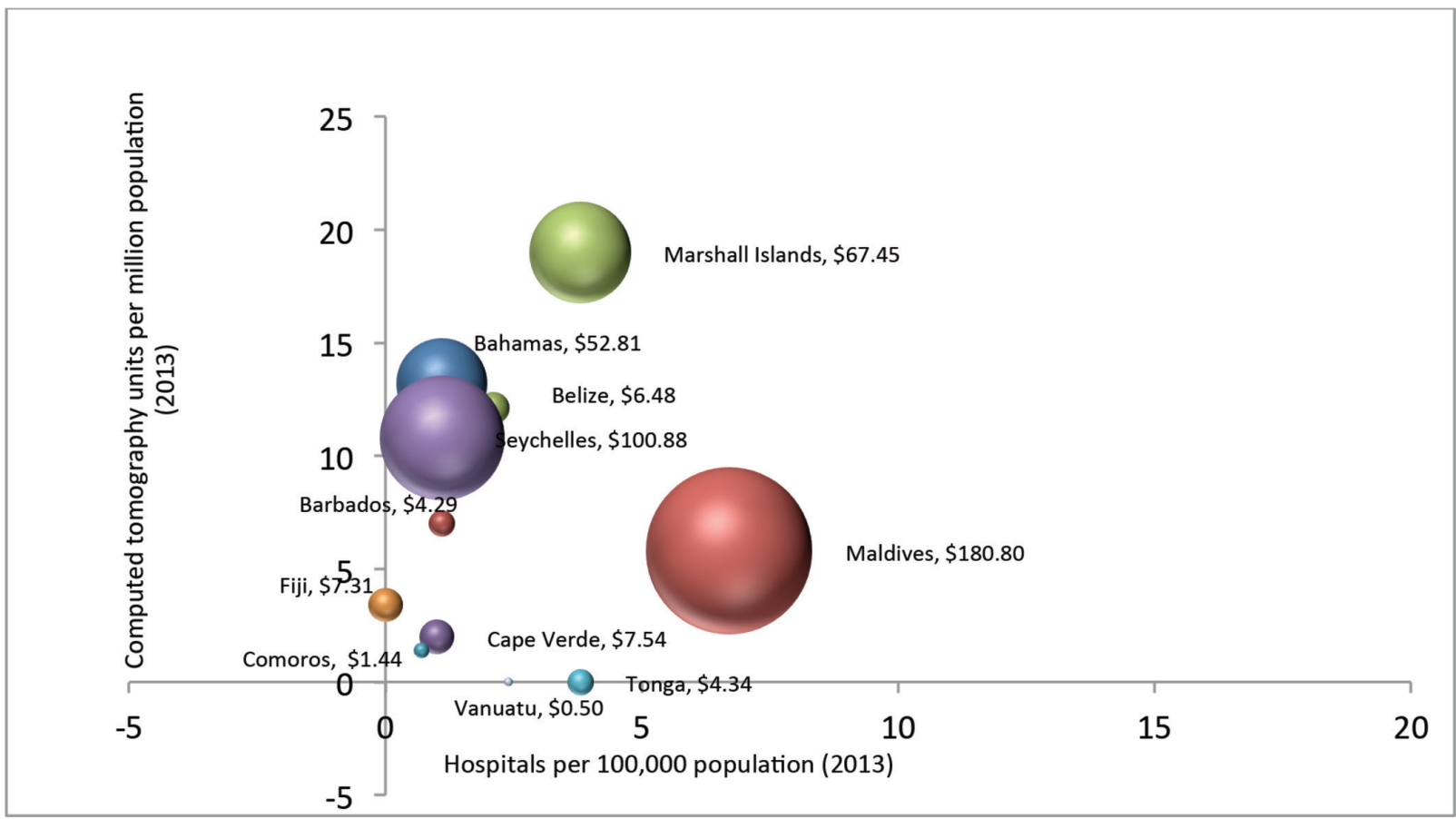

Figure 6 Expenditure on health-related travel per capita versus density of health infrastructure and technologies, 2013. 
Table 5 Description of public schemes for medical travel in Tuvalu and Maldives

Tuvalu model Maldives model

Is there a national policy Tuvalu Medical Treatment Scheme (TMTS): medical 'Husnuvaa Aasandha': universal healthcare to fund medical travel referral scheme with Fiji introduced in $2005^{19}$ and programme in the Maldives that subsidises for overseas? partner of medical treatment scheme with New overseas treatment, introduced in 2012. Zealand.

How the programme works:

\begin{tabular}{|c|c|}
\hline Approach & $\begin{array}{l}\text { Multilateral: government-to-government } \\
\text { programme. Other countries participating in the } \\
\text { medical treatment scheme with New Zealand are } \\
\text { Fiji, Kiribati, Tonga and Vanuatu }\end{array}$ \\
\hline Goal & $\begin{array}{l}\text { Provide access to specialist care not available } \\
\text { for citizens in Fiji, Kiribati, Tonga, Vanuatu and } \\
\text { Tuvalu. Also provides a visiting medical specialist } \\
\text { programme. }\end{array}$ \\
\hline $\begin{array}{l}\text { Management of the } \\
\text { scheme }\end{array}$ & $\begin{array}{l}\text { Each country maintains an incountry overseas } \\
\text { referral committee (ORC) that manages the } \\
\text { scheme, handling all aspects of the referral until } \\
\text { the patient arrives overseas. }\end{array}$ \\
\hline Financing & $\begin{array}{l}\text { Participating countries make annual contributions } \\
\text { for the scheme through bilateral discussions. }\end{array}$ \\
\hline
\end{tabular}

Bilateral: government-to-foreign provider programme. Participating countries are the Maldives, India and Sri Lanka.

The Aasandha office is established in Sri Lanka to serve Maldivians seeking treatment in Sri Lanka under the government subsidy.

Provide access to services unavailable in the Maldives.

The scheme is implemented by an insurance company, Aasandha Private Ltd at a contracted price of 2750 Maldivian Rufiyah (MRFf per person for the first year (2012)

Paid directly to the contracted providers through the Maldivian government general revenues on a fee for service basis.

$\begin{array}{ll}\text { Purchasing } & \text { Health specialists/providers are under contract } \\ \text { with New Zealand's International Aid \& } \\ \text { Development Agency } \\ \text { Specialist teams from New Zealand are sent to } \\ \text { partner countries of the scheme. }\end{array}$

Through contracted hospitals in India and Sri Lanka on a fee-for-service basis. Contracts are annually renewed.

Scheduled visits by mobile teams of specialists are done on a regular basis.

Eligibility (clinical/ non-clinical)

Referrals are made based on appropriate specialist advice and supported by the participating country's ORC.

There is good prognosis for the patient living and improved quality of life for at least 5 years after treatment according to clinical evidence and advice.

\begin{tabular}{|c|c|c|}
\hline Exclusions & $\begin{array}{l}\text { Chronic cardiac failure, chronic renal failure, } \\
\text { chronic lung conditions, chronic neurological } \\
\text { conditions and conditions requiring heart, renal or } \\
\text { bone marrow transplants are excluded. } \\
\text { Patients who have significant medical conditions } \\
\text { other than that for which they are being referred } \\
\text { (eg, coexisting renal disease) and/or conditions } \\
\text { that will incur ongoing costs that are unable to be } \\
\text { met by partner government health funds. }\end{array}$ & $\begin{array}{l}\text { Offers a comprehensive package with few } \\
\text { exclusions such as cosmetic surgeries, } \\
\text { dental, nutritional supplements, treatments for } \\
\text { addictions, counselling, weight loss, abortions, } \\
\text { infertility and complimentary medicines. }\end{array}$ \\
\hline Expenses covered & $\begin{array}{l}\text { Treatment cost, food, accommodation, small } \\
\text { allowance and travel expenses. }\end{array}$ & $\begin{array}{l}\text { Treatment costs, tickets for patient and one } \\
\text { caregiver. }\end{array}$ \\
\hline Coverage statistics & $\begin{array}{l}\text { In } 2013 \text { TMTS spent \$A } 2.1 \text { million, which is } \\
44.5 \% \text { of the health budget, where } 99 \text { patients } \\
\text { (approximately } 0.9 \% \text { of the population) were } \\
\text { subsidised by the government. }\end{array}$ & $\begin{array}{l}\text { In } 2013 \text {, Aasandha spent US } \$ 4.8 \text { million } \\
\text { on } 3456 \text { visits (approximately } 0.9 \% \text { of the } \\
\text { population) that were subsidised for medical } \\
\text { travel. }\end{array}$ \\
\hline Tradeoffs & $\begin{array}{l}\text { Sacrifices half the health budget that could be } \\
\text { used for other health services such as primary } \\
\text { healthcare. }\end{array}$ & $\begin{array}{l}\text { High out-of-pocket expenditure on medical } \\
\text { travel by patients who choose to self-fund their } \\
\text { treatments. }\end{array}$ \\
\hline
\end{tabular}

The three largest 'bubbles', representing high levels of per capita medical travel spending, by Tuvalu (\$156.9), the Maldives (\$113.2) and the Seychelles $(\$ 100.8)$ had public funds available for medical travel, which implies that medical travel is facilitated by the availability of government subsidy. The Tuvalu Medical Treatment 
Scheme (TMTS) signed between Tuvalu and overseas hospitals in the region spent $44.5 \%$ of its health budget on overseas treatment in $2013,{ }^{19}$ while the Maldives under its scheme 'Aasandha' spent $\$ 11.6$ million on subsidised travel in Indian and Sri Lankan hospitals in $2012^{20}$ and treatments worth $\$ 1.53$ million per annum are funded by the Seychelles government. ${ }^{21}$ Evidence has shown that public financing for health has the potential to reduce inequities, and an investigation of equity measures with regard to public financing of overseas treatment in the Maldives has been reported elsewhere. Investments in highly technological specialist care in very small populations, and geographical formations of these island nations may not be economically feasible. Yet, the cost-effectiveness of public financing for health-related travel needs to be explored and compared with alternatives such as the establishment of services locally.

The examples of Tuvalu and the Maldives demonstrate that access to health services that were not feasible to be established in these countries can be provided through the import of health services. Analysis of claims data from the National Social Protection Agency of the Maldives showed that the number of beneficiaries subsidised for treatment abroad increased by $199 \%$ and average expenditure per beneficiary increased $49.7 \%$ during 2010 and 2013. ${ }^{22}$ The TMTS, introduced in 2005, has increased its expenditure from approximately $\$ 0.3$ million to $\$ 1.5$ million in 2013 , and a preliminary analysis of the expected reforms of the scheme suggests that a per-patient saving of \$A 15000 can be achieved by the government of Tuvalu by referring cardiac cases to India. ${ }^{19}$ These public schemes were different in approach, design and coverage. With a direct government to foreign provider approach, the Maldives appears to be providing a more comprehensive set of services to a greater number of patients at a smaller per capita health budget, while the multilateral approach by Tuvalu is likely to have contributed to reducing the burden of OOP maintained at an average of $0.1 \%$ over the past decade. The lack of a private sector in the Tuvaluan health system and predominant public funding of health services also contribute to this. Both the schemes have attracted critique from international organisations such as the IMF and WB, and policy documents of Tuvalu and the Maldives have highlighted the opportunity cost of these schemes. These costs include: lost incentive to improve or expand access to the domestic health system, lost continuums of care, maldistribution and skill mix imbalances of health workers ${ }^{23}$ and cost of complications that has to be borne by domestic health systems. ${ }^{24}$ In the Maldives, the cost of the scheme itself is very high, whereby the median expenditure per beneficiary has increased from $\$ 605$ in 2010 to $\$ 739$ in 2013. ${ }^{25}$ The Maldives health policy notes by the WB questioned the fiscal sustainability of the scheme in the long run calling for negotiated close-ended package rates with foreign providers and for targeted subsidies for highly complex treatments only. ${ }^{20}$ The health master plan of the Maldives 2016-2025 has also cautioned the tendency of overutilisation of services due to the perception that the current scheme is 'unlimited', which has resulted in inefficient use of resources especially in the absence of a gate-keeping system. ${ }^{26}$ The IMF in its latest country report of Tuvalu noted the potential overspending of the TMTS programme and advised the authorities to improve the cost-effectiveness of its policy. The strategic health plan of Tuvalu 2009-2018 further noted that the TMTS put a significant drain on public resources threatening its ability to maintain other health services in the country. ${ }^{27}{ }^{28}$ Hence, maintaining a balance in the ratio of expenditure on preventive and curative healthcare is vital if import of health services is implemented as a solution to achieve UHC.

This study relies on international indicators that have limitations in methodology and application in different countries. A review of literature that used indicators as a measurement of health system performance showed that there were differences in the adoption of indicators by developing and developed countries ${ }^{29}$ and the composition of SIDS in this study included high-income, upper-middle-income, low-and-middle-income and low-income countries, which may limit the generalisability of study findings. We address the issue of data in online supplementary annex 1, which details data sources used by the SIDS to report to the IMF. Data on the volume of travel may have given better insight on trends in medical travel. The IMF member states have also used combination of methods to report travel data, which may result in underestimation or over-estimation of travel data in these countries. However, this study has used panel data of travel expenditures of 10 years and, where possible, panel data of indicators too, to minimise such overestimations and underestimations reflected in 1 or 2 years of data.

\section{CONCLUSION}

The trend in health-related travel among SIDS has over the last 10 years followed the global trend-rising yet heterogeneous. The pattern also demonstrated a volatility to global events, a factor that needs to be taken into consideration by SIDS considering import as a mechanism to increase access to health services.

SIDS generally lacked the health technologies needed to achieve UHC. The two island states with the highest per capita expenditures on the import of health services had publicly funded schemes to manage the process. Assessment of the Tuvaluan and Maldivian public schemes to subsidise medical travel have demonstrated that access to specialised, technology-driven health services can be increased through import of health services. Our findings suggest that import of health services is a potential mechanism to help achieve UHC but highlight the need for due diligence over cost, equity and quality control.

Funding This research received no specific grant from any funding agency in the public, commercial or not-for-profit sectors.

Competing interests None declared. 
Provenance and peer review Not commissioned; externally peer reviewed.

Data sharing statement All the data used in this study are publicly available.

Open Access This is an Open Access article distributed in accordance with the Creative Commons Attribution Non Commercial (CC BY-NC 4.0) license, which permits others to distribute, remix, adapt, build upon this work non-commercially, and license their derivative works on different terms, provided the original work is properly cited and the use is non-commercial. See: http://creativecommons.org/ licenses/by-nc/4.0/

(C) Article author(s) (or their employer(s) unless otherwise stated in the text of the article) 2018. All rights reserved. No commercial use is permitted unless otherwise expressly granted.

\section{REFERENCES}

1. Evans DB, Hsu J, Boerma T. Universal health coverage and universal access. Bull World Health Organ 2013;91:546.

2. Transforming our world: the 2030 agenda for sustainable development, 2015

3. WHO. What is universal health coverage? 2016. Online Questiona and answer archives http://www.who.int/features/qa/universal health coverage/en/

4. The United Nations. List of small island developing states: The United Nations, 2013. http://www.un.org/special-rep/ohrlls/sid/list. htm

5. Calì JKaM. The Global Downturn and Trade Prospects for Small States. Commonwealth trade hot topics. $2009 \mathrm{http}: / /$ publications. thecommonwealth.org/QuickSearchResults.aspx

6. Guillotreau P, Campling L, Robinson J. Vulnerability of small island fishery economies to climate and institutional changes. Curr Opin Environ Sustain 2012;4:287-91.

7. Walls HL, Smith RD, Drahos P. Improving regulatory capacity to manage risks associated with trade agreements. Global Health 2015;11:1.

8. Hanefeld J, Smith R, Horsfall D, et al. What do we know about medical tourism? A review of the literature with discussion of its implications for the UK National Health Service as an example of a public health care system. $J$ Travel Med 2014;21:410-7.

9. Papanicolas I, Smith P. Health system performance comparison: an agenda for policy, information and research: an agenda for policy, information and research: McGraw-Hill Education (UK), 2013.

10. WHO. Everybody business: strengthening health systems to improve health outcomes: WHO's framework for action. Geneva 2007.

11. Fund IM. Balance of Payments Manual. 6th edn: International Monetary Fund, 2016. http://www.imf.org/external/pubs/ft/bop/ 2014/pdf/GuideFinal.pdf

12. Lunt N, Horsfall D, Hanefeld J. Handbook on medical tourism and patient mobility: Edward Elgar Publishing, 2015.

13. Johnston R, Crooks VA, Snyder J, et al. What is known about the effects of medical tourism in destination and departure countries? A scoping review. Int J Equity Health 2010;9:24

14. Forgione DA, Smith PC. Medical tourism and its impact on the US health care system. J Health Care Finance 2007;34:27-35.

15. Noree T, Hanefeld J, Smith R. Medical tourism in Thailand: a crosssectional study. Bull World Health Organ 2016;94:30-6.
16. Forum WE. The travel and tourism competetiveness report 2011 Beyond the Downturn, 2016.

17. Nazem G, Mohamed B. Understanding medical tourists' perception of private hospital service quality in Penang Island. Asian Culture and History 2015;8:100.

18. Johnston R, Crooks V, Snyder J, et al. An overview of barbados' medical tourism industry-version 2.0. 2013.

19. Bank TW. International development associationprogram document for a proposed development policy grant in the amount of SDR $1.1 \mathrm{~m}$ to Tuvalu for a 2nd development policy operation, 2015. Contract No: Report No. 94359 - TV.

20. Nagpal SRS. Utilization trends and cost containment options for Aasandha, 2014. http://documents.worldbank.org/curated/en/ 2013/03/18304510/utilization-trends-cost-containment-optionsaasandha

21. Organization WWH. Sychelles WHO country corporation strategy 2008-2013. 2009 http://www.who.int/countryfocus/cooperation strategy/ccs_syc_en.pdf (cited 15 May 2016).

22. Suzana M, Mills A, Tangcharoensathien V, et al. The economic burden of overseas medical treatment: a cross sectional study of Maldivian medical travelers. BMC Health Serv Res 2015;15:1.

23. Helble M. The movement of patients across borders: challenges and opportunities for public health. Bull World Health Organ 2011;89:68-72.

24. Hanefeld J, Horsfall D, Lunt N, et al. Medical tourism: a cost or benefit to the NHS? PLoS One 2013;8:e70406.

25. Suzana M, Chongsuvivatwong V. Changes in access to and costs of overseas treatment after the introduction of universal health coverage in the Maldives: Findings from surveys and the analysis of claims data. Health Serv Manage Res 2015;28:47-57.

26. Ministry of Health M. Maldives health master plan 2016-2025. Maldives: Ministry of Health Maldives, 2014.

27. Health Mo. Strategic health plan 2009-2018: Ministry of Health Tuvalu, 2009.

28. IMF. 2014 Article IV consultation - staff report; Press release; and statement by the executive director for Tuvalu: International Monetary Fund, 2016. http://www.imf.org/external/pubs/ft/scr/2014/ cr14253.pdf (cited 15 May 2016).

29. Kruk ME, Freedman LP. Assessing health system performance in developing countries: a review of the literature. Health Policy 2008;85:263-76.

30. Group TWB. World development indicators: health systems. 2014 http://wdi.worldbank.org/table/2.15 (cited 29 July 2014).

31. Bank TW. World Integrated trade solution: trade statistics. 2016 http://wits.worldbank.org/Default.aspx

32. WHO. World Health Statistics: World Health Organization, 2015.

33. WHO. Tuvalu country corporation strategy: World Health Organization, 2014. http://www.who.int/countryfocus/cooperation_ strategy/ccsbrief_tuv_en.pdf

34. Health Mo. Maldives National Health Accounts 2009-2011: National Social Protection Agency Maldives (NSPA), 2013.

35. Nagpal SRS. Health expenditure, equity and evolution of Aasandha2013. http://www-wds.worldbank.org/external/default/W DSContentServer/WDSP/IB/2013/09/26/000333037_20130926111127/ Rendered/PDF/812480BRIOP12100Box037933B00PUBLIC0.pdf

36. Organization WWH. Country corporation strategy Maldives 2013-2017: Maldives, 2016. http://www.who.int/countryfocus/ cooperation strategy/ccs mdv_en.pdf 